\section{Evaluation of Allelopathic Potential of Wood Chips for Weed Suppression in Horticultural Production Systems}

\author{
Bala Rathinasabapathi, ${ }^{1}$ James Ferguson, and Mark Gal \\ Horticultural Sciences Department, University of Florida, Gainesville, \\ FL 32611-0690 \\ Additional index words allelopathy, biomass, florida beggarweed, Desmodium tortuosum, \\ phenolics, red cedar, Juniperus silicicola, weed management
}

\begin{abstract}
Shredded and chipped wood mulches are used for weed suppression in perennial fruit crops, in urban landscapes, and occasionally in vegetable crops. Wood chip mulches with weed-suppressing allelochemicals may be more effective for weed control, especially under sustainable and organic production systems, than mulches without such properties. The objective of this study was to test for the presence of water-soluble allelochemicals in wood chips derived from tree species, often found in wood resource recovery operations in the southeastern US. Presence of allelochemicals in water eluates of woodchips and leaves was evaluated in a lettuce bioassay. Eluates of wood chips from red maple (Acer rubrum L.), swamp chestnut oak (Quercus michauxii Nutt.), red cedar (Juniperus silicicola L.H. Bailey), neem (Azadirachta indica A. Juss.), and magnolia (Magnolia grandiflora L.) highly inhibited germinating lettuce seeds, as assessed by inhibition of hypocotyl and radicle growth. The effects of wood chip eluates from these five species were more than that found for eluates from wood chips of black walnut (Juglans nigra L.,) a species previously identified to have weed-suppressing allelochemicals. Tests on red cedar, red maple, and neem showed that water-soluble allelochemicals were present not only in the wood but also in the leaves. In greenhouse trials, red cedar wood chip mulch significantly inhibited the growth of florida beggarweed (Desmodium tortuosum DC.), compared to the gravel-mulched and no-mulch controls.
\end{abstract}

Shredded and chipped wood mulches are sometimes used for weed suppression in the production of perennial fruit crops (Foshee et al., 1996; Smith et al., 2000) especially in organic farming. They are also popular in urban landscapes and are occasionally used in vegetable crop production (Duryea, 2000; Guertal and Edwards, 1996). Wood mulch is a convenient, cheap, renewable and often, locally available natural resource for weed suppression, and is of special importance in organic and sustainable production systems where chemical herbicides are not desirable. With an annual production of 38 million metric tons of urban tree residue (National Research Council, 2000), recycled wood of selected species could provide new horticultural products and market niches.

Allelochemicals are phytochemicals produced by one plant inhibiting or enhancing the growth of neighboring plants (Ferguson and Rathinasabapathi, 2003). Many plant species are known to contain growth-inhibitory phytochemicals and some of them have been studied for their effects on the plants ecosystem (Lydon and Duke, 1989). We hypothesized that wood mulches containing growth-inhibitory allelochemicals can be more effective for weed suppression than mulches without such al-

Received for publication 20 Aug. 2004. Accepted for publication 20 Sept. 2004. Research supported by the University of Florida School of Natural Resources and Environment Biomass Center. Florida Agricultural Expt. Station journal series R-10208.

${ }^{1}$ Corresponding author; e-mail brath@mail.ifas. ufl.edu. leochemicals. To our knowledge, wood mulch materials have not been screened for the presence of weed-suppressing allelochemicals. The objective of the current study was to evaluate eluates of wood chips from red maple (Acer rubrum L.), swamp chestnut oak (Quercus michauxii Nutt.), red cedar (Juniperus silicicola L.H. Bailey), neem (Azadirachta indica A. Juss.), and magnolia (Magnolia grandiflora L.) for their allelopathic potential as assessed by inhibition of hypocotyl and radicle growth in the lettuce bioassay. Leaves of red cedar, red maple, and neem were also examined. In greenhouse trials, inhibition of the growth of florida beggarweed (Desmodium tortuosum DC.) by red cedar wood chip mulch was compared to the gravel-mulched and mulchfree controls.

\section{Material and Methods}

Wood and plant material. For an initial screen, tree limbs with leaves were collected from a wood resource recovery facility (Alachua County, Fla.) and the species were identified based on morphological traits. Other wood samples were obtained from $>5$-year-old trees in Gainesville. The species tested were black walnut (Juglans nigra), brazilian pepper (Schinus terebinthifolius), camphor tree (Cinnamomum camphora), laurel oak (Quercus hemispherica), loblolly pine (Pinus taeda), magnolia (Magnolia grandiflora), neem (Azadirachta indica), oleander (Nerium oleander), red maple(Acer rubrum), red cedar(Juniperus cilicicola), swamp chestnut oak (Quercus mi- chauxii), sweet gum(Liquidambar styraciflua), sweet viburnam (Viburnam odorattisimum), and water oak (Quercus nigra). Stems of 0.5 $\mathrm{cm}$ diameter were cut into 2.5 -cm-long pieces and used immediately for the preparation of eluates. Florida beggarweed seeds were collected from a field in Gainesville, Fla.

Preparation of water eluates. Wood pieces ( $5 \mathrm{~g}$ fresh weight) were incubated in $50 \mathrm{~mL}$ double distilled water for $24 \mathrm{~h}$ at $37{ }^{\circ} \mathrm{C}$ in a temperature-controlled incubator. The liquid was filtered through four layers of cheese cloth and a 0.2 micron $\mathrm{CN}$ filter unit (Nalge-Nunc International, Rochester, N.Y.). The filtersterilized eluates were stored at $4{ }^{\circ} \mathrm{C}$ until use in the bioassay. Where indicated, a similar procedure was used to prepare an eluate of leaves except $75 \mathrm{~mL}$ of water was used for every $5 \mathrm{~g}$ fresh weight. In some experiments, a second eluate (eluate 2 ) was made from the same wood or leaf sample, by adding $50 \mathrm{~mL}$ or $75 \mathrm{~mL}$ of water immediately after removing the first eluate.

Lettuce bioassay for allelopathy. Seeds of lettuce Lactuca sativa L. 'Green Ice' were purchased from Park Seed (Greenwood, S.C.) and stored at $4{ }^{\circ} \mathrm{C}$ until the day of use. Seeds were surface-sterilized by rinsing in $10 \%(\mathrm{v} / \mathrm{v})$ commercial bleach with $0.05 \%(\mathrm{v} / \mathrm{v})$ Tween 20 (Fisher Scientific, Pittsburgh, Pa.) and thoroughly washed in sterile distilled water. An autoclaved Whatman No. 2 filter paper circle was placed inside a sterile disposable petri dish $(100 \times 15 \mathrm{~mm})$ and the paper was wetted by adding either $3 \mathrm{~mL}$ of sterile water (control) or $3 \mathrm{~mL}$ of the test eluate. Surfacesterilized seeds ( 18 to 20 per plate) were placed on the wet filter paper discs and the petri dishes were sealed using parafilm. The plates were incubated at $24^{\circ} \mathrm{C}$ under a light bench with an 11-h light cycle of PPFD $12 \mu \mathrm{mol} \cdot \mathrm{m}^{-2} \cdot \mathrm{s}^{-1}$. Follwing 48 or $72 \mathrm{~h}$, germination percentage, the lengths of radicle, hypocotyl, and cotyledons were measured. In each experiment, the negative control was water and the positive control was a 24-h eluate made from black walnut wood chips.

Greenhouse experiments on weed suppression. Seeds of florida beggarweed were germinated in a pot in a commercial potting medium (Metro-Mix 300, Scotts-Sierra, Marysville, Ohio). Uniform-sized 1-month old seedlings were transplanted in Metro-Mix 300, in 3.8-L plastic pots at the rate of one plant per pot. Ten plants were not mulched (control), another ten plants were mulched with gravel to a 5-cm depth (control) and another ten pots were mulched with red cedar wood mulch to a 5 -cm depth. The pots were irrigated to container capacity on a daily basis. One greenhouse experiment was conducted in Gainesville during Fall 2003 (40 d duration) and a second during spring, 2004 (46 d).

Statistical treatment. Experiments were set up using a completely randomized design and analyses of data were performed using the SAS statistical package (SAS Institute, 2000). Following analysis of variance, Duncan's multiple range test was used for mean comparisons.

Each bioassay experiment was done twice using wood chips collected at two different 

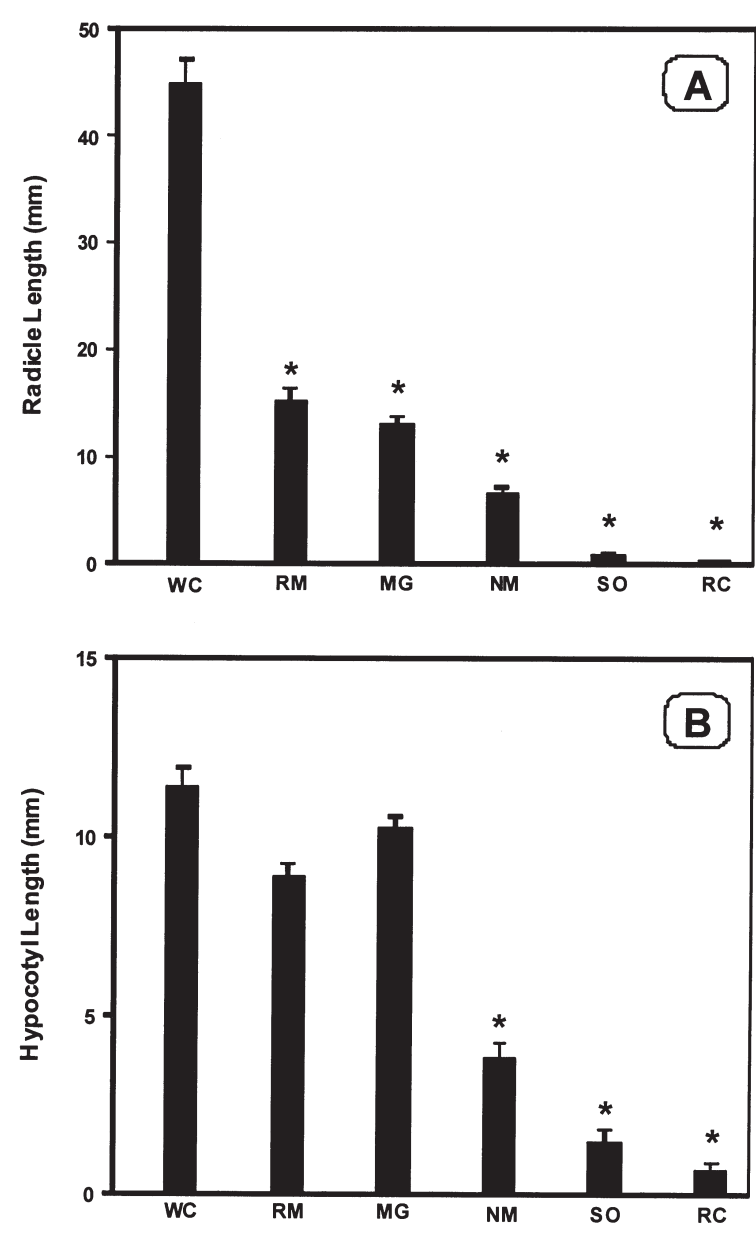

times of the year from different sources and representative results are shown in the results section.

\section{Results}

Development of a bioassay for allelopathy. A bioassay for testing for the presence of growth-inhibitory allelochemicals in wood chips was developed. The final details of the method described here were based on initial experiments wherein elements of the method were optimized using black walnut wood chips and lettuce seed germination (J. Ferguson, unpublished). Black walnut was long known to contain allelopathic quinones (Davis, 1928). In an initial screen of thirteen species of trees, we identified five species that inhibited germinating lettuce more severely than the eluates from black walnut wood based on a visual score. The five species identified in our initial screen are the subject of the current study.

Allelopathic potential of wood chips. Water eluates of wood chips from red maple, swamp chestnut oak, red cedar, neem, and magnolia significantly inhibited the radicle of germinating lettuce (Fig. 1A). Eluates of wood chips from neem, red cedar, and swamp chestnut oak also inhibited the hypocotyl growth (Fig. 1B). Cotyledon length was not significantly inhibited (data not shown). Radicle growth was inhibited more severely than that of the hypocotyl (Fig. 1A and B). Radicle tips of
Fig. 1. Radicle (A) and hypocotyl lengths (B) of lettuce seedlings, for seeds germinated in water (WC), or water eluates of wood chips of red maple (RM), magnolia (MG), neem (NM), swamp chestnut oak (SO), and red cedar (RC) scored $72 \mathrm{~h}$ after sowing. The values are means \pm standard errors $(n=18)$. The means significantly different from the water control are marked with an asterix.

the inhibited seedlings were often brown or black (data not shown). The inhibitory effect of these eluates were significantly reduced if the eluates were autoclaved (data not shown) or the wood chips were derived from 1 -year-old seedlings (data not shown) instead of five year old or older trees used in the study described here.

Red cedar, red maple, and neem leaves and wood contain allelochemicals. To test whether species that contain allelochemicals in the wood would also have such potential in their leaves, water eluates from both the wood and leaves were compared for red cedar, red maple, and neem. In all three species, both the wood and the leaf eluates inhibited germinating lettuce seedlings (Table 1). Leaf eluates were generally more effective than wood chips (Table 1). Second eluates of wood chips of red maple and red cedar and leaves of red cedar were more effective than the first eluate (Table 1) suggesting that $24 \mathrm{~h}$ incubations are inadequate to extract all the growth-inhibitory principles in these species and tissue.

Red cedar mulch inhibits growth of florida beggarweed. Two greenhouse trials were conducted to test whether red cedar wood chip mulch could inhibit beggarweed, commonly found in Florida citrus groves. In both fall and spring trials, the growth of florida beggarweed as measured by height and above ground biomass at harvest, was significantly $(P<0.05)$ inhibited by the wood chip mulch compared to no mulch or gravel mulch controls (Table 2). Gravel mulch control did not significantly reduce biomass or height compared to the no-mulch control. However, the wood mulch did reduce weed growth (Table 2), suggesting that biological or chemical factors associated with wood chip mulch may be responsible for the inhibition of the test weed.

\section{Discussion}

We used a rapid and simple bioassay to assess the presence of water-soluble allelochemicals in wood chips. Lettuce was chosen for the bioassay since the seeds germinate in a short period and previous studies have found lettuce bioassays to be highly sensitive to allelochemicals (Macias et al., 1993; Yu and Matsui, 1994; Veronneau et al., 1997). We focused on only water-soluble compounds that could be eluted in 24 or $48 \mathrm{~h}$, because of their relevance in a field situation. Rain or irrigation water can be expected to leach compounds from wood chip mulch. The present study used only thin wood material $(0.5 \mathrm{~cm}$ diameter) for the sake of uniformity and convenience in sample preparation. Future studies are needed to explore wood material of differing maturity and thickness.

Certain benefits from phytochemicals in organic mulches have been recognized in previous studies (Lazzeri and Mancini, 2001), but systematic screening of wood chip mulch for weed-suppressing chemicals has not been done. Results presented here indicate that germinating lettuce seedlings were highly inhibited by water eluates of wood chips from several tree species including red maple, magnolia, swamp chestnut oak, red cedar, and neem. Some of these tree species are already known to contain bioactive compounds (Aerts and Mordue, 1997; Johnson, 1999; Abou-Zaid et al., 2001) but their wood have not been examined for plant growth inhibiting potentials. It is likely that other members of botanical families where these trees belong namely Aceraceae, Cuppressaceae, Fagaceae, Magnoliaceae, and Meliaceae could be targeted for screening bioactive compounds.

At least three tree species, red cedar, red maple, and neem contained growth inhibitory substances in both the wood and leaves. This suggests that a systematic testing of all parts

Table 1. Effect of water eluates of red cedar, red maple and neem wood chips and leaf tissue on the radicle growth of germinating lettuce seeds, measured $48 \mathrm{~h}$ after sowing. Means $(\mathrm{n}=20)$ followed by different letters are significantly different at $P \leq 0.05$.

\begin{tabular}{lccc}
\hline Species & Tissue & Eluate & $\begin{array}{c}\text { Mean radicle } \\
\text { length (mm) }\end{array}$ \\
\hline Water control & None & None & $15.42 \mathrm{a}$ \\
Red cedar & Wood chip & Eluate 1 & $9.84 \mathrm{c}$ \\
Red cedar & Wood chip & Eluate 2 & $5.70 \mathrm{~d}$ \\
Red cedar & Leaf & Eluate 1 & $12.95 \mathrm{~b}$ \\
Red cedar & Leaf & Eluate 2 & $2.28 \mathrm{e}$ \\
Red maple & Wood chip & Eluate 1 & $10.95 \mathrm{c}$ \\
Red maple & Wood chip & Eluate 2 & $5.90 \mathrm{~d}$ \\
Red maple & Leaf & Eluate 1 & $2.83 \mathrm{e}$ \\
Red maple & Leaf & Eluate 2 & $2.80 \mathrm{e}$ \\
Neem & Wood chip & Eluate 1 & $6.65 \mathrm{~d}$ \\
Neem & Wood chip & Eluate 2 & $10.32 \mathrm{c}$ \\
Neem & Leaf & Eluate 1 & $2.18 \mathrm{e}$ \\
Neem & Leaf & Eluate 2 & $6.72 \mathrm{~d}$ \\
\hline
\end{tabular}


Table 2. Growth inhibition of florida beggarweed by red cedar wood chip mulch. Values are means of 10 plants in each treatment. Within each column, means followed by different letters are significantly different by $P<0.05$ by Duncan's multiple range test.

\begin{tabular}{|c|c|c|c|c|}
\hline \multirow[b]{2}{*}{ Treatment } & \multicolumn{2}{|c|}{ Fall 2003} & \multicolumn{2}{|c|}{ Spring 2004} \\
\hline & $\begin{array}{c}\text { Plant ht } \\
\text { at harvest } \\
(\mathrm{mm})\end{array}$ & $\begin{array}{c}\text { Aboveground } \\
\text { biomass/plant } \\
\text { (g) }\end{array}$ & $\begin{array}{c}\text { Plant ht } \\
\text { at harvest } \\
(\mathrm{mm})\end{array}$ & $\begin{array}{c}\text { Aboveground } \\
\text { biomass/plant } \\
\text { (g) }\end{array}$ \\
\hline Control & $731 \mathrm{a}$ & $3.0 \mathrm{a}$ & $260 \mathrm{a}$ & $3.3 \mathrm{a}$ \\
\hline Gravel mulch & $758 \mathrm{a}$ & $3.3 \mathrm{a}$ & $305 \mathrm{a}$ & $4.1 \mathrm{a}$ \\
\hline Red cedar mulch & $700 \mathrm{~b}$ & $2.5 \mathrm{~b}$ & $192 \mathrm{~b}$ & $1.8 \mathrm{~b}$ \\
\hline
\end{tabular}

of trees will be needed to identify tissues with high concentration of bioactive substances. Leaves containing allelochemicals may also be applied as mulch for weed control and leaves could represent a more sustainable biomass for continuous harvest.

Currently the nature of the growth inhibiting substances in these wood chips and leaves is not known. Many secondary products, especially phenolic compounds were identified to exhibit allelopathic properties in plants (Lydon and Duke, 1989) and wood tissue is often rich in polyphenolics (Haslam, 1989). Hence, it is possible that certain specific polyphenolics in the water eluates from these species exhibit allelopathic activities.

In greenhouse trials, growth of florida beggarweed was significantly reduced by red cedar wood chips. This suggests that organic mulch with allelopathic potential can be effective for weed suppression in the field. Future field trials are needed to evaluate allelopathic wood chip and leaf mulches for post-emergence and pre-emergence suppression of a number of weed species and to test the effects of those mulches on crops.
Guertal,E.A. and J.H. Edwards. 1996. Organic mulch and nitrogen affect spring and fall collard yields. HortScience 31:823-826.

Haslam, E. 1989. Plant polyphenols: Vegetable tannins revisited, p. 230. Cambridge Univ. Press, Cambrdige.

Johnson, K.S. 1999. Comparative detoxification of plant (Magnolia virginiana) allelochemicals by generalist and specialist saturniid silkmoths. J. Chem. Ecol. 25:253-269.

Lazzeri, L, and L.M. Manici. 2001. Allelopathic effect of glucosinolate-containing plant green manure on Pythium sp. and total fungal population in soil. HortScience 36:1283-1289.

Abou-zaid, M., B.V. Helson, C. Nozzolillo, and T. Arnason. 2001. Ethylm-digallate from red maple Acer rubrum L., as the major resistance factor to forest tent caterpillar Malacosoma disstria $\mathrm{Hbn}$. J. Chem. Ecol. 27:2517-2527.

Aerts, R.J. and A.J. Mordue. 1997. Feeding deterrence and toxicity of neem triterpenoids. J. Chem. Ecol. 23:2117-2132.

Davis, E.F. 1928. The toxic principle of Juglans nigra as identified with synthetic juglone and its toxic effects on tomato and alfalfa plants. Amer. J. Bot. 15:620.

Davis, J.M. 1994. Comparison of mulches for fresh-market basil production. HortScience 29:267-268.

Duryea, M.L. 2000. Landscape mulches: What are the choices in Florida, p. 1-5. Univ. Fla. Coop. Ext. Serv. FOR 80. http://edis.ifas.ufl.edu.

Ferguson, J. and B. Rathinasabapathi. 2004. Allelopathy: How plants suppress other plants, p. 1-3. Univ. Fla. Coop. Ext. Serv., HS944. http://edis.ifas.ufl.edu.

Foshee, W.G., W.D. Goff, K.M. Tilt, J.D. Williams, J.S. Bannon, and J.B. Witt. 1996. Organic mulches increase growth of young pecan trees. HortScience 31:811-812.
Lydon, J. and S.O. Duke. 1989. The potential of pesticides from plants. p. 1-41. In: L.E. Cracker and J.E. Simon (eds.). Herbs, spices and medicinal plants: Recent advances in botany, horticulture and pharmacology. vol 4., Oryx Press, Ariz.

Macias, F.A., R.M. Varela, A. Torres, and J.M.G. Molinillo. 1993. Potential allelopathic guaianolides from cultivar sunflower leaves, var SH-222. Phytochemistry 34:669-674.

National Research Council. 2000. Biobased industrial products: Priorities for research and commercialization, p. 30. National Academy Press, Wash. D.C

SAS Institute. 2000. SAS/graph user's guide. version 8.01. SAS Inst., Cary, N.C.

Smith, M.W., B.L. Carroll, and B.S. Cheary. 2000. Mulch improves pecan tree growth during orchard establishment. HortScience 35:192-195.

Veronneau, H., A. F. Greer, S. Daigle, and G. Vincent. 1997. Use of mixtures of allelochemicals to compare bioassays using red maple, pin cherry, and american elm. J Chem. Ecol. 23:1101-1117.

Yu, J.Q. and Y. Matsui. 1994. Phytotoxic substances in root exudates of cucumber (Cucumis sativus L.). J. Chem. Ecol. 20:21-31. 